\title{
Determination of Optimal Irrigation Scheduling for Sesame (Sesamum indicum L.) at Dubti, Afar National Regional State of Ethiopia
}

\author{
Oumer Assfaw \\ Dubti Pastoral and Agro-Pastoral Research Center, Semera, Ethiopia
}

\begin{abstract}
Irrigation means applying adequate water at the right time to crops in the right amount. Irrigation timetable is essential for the development of best irrigated area management practices. A significant concern has become the sustainable use of water in agriculture. The adoption of irrigation water saving and the maintenance of acceptable yields could help preserve this ever more restricted resource In most cases, its humidity before and after irrigation has not been checked in Ethiopia. Although irrigation has been practiced for a long time, farmers have limited experience of this. It is therefore very important to monitor soil moisture levels for effective management of irrigation water. For three successive years, a field study was conducted to determine the optimum irrigation schedule for sesame production at Dubti. The study's goals were to evaluate the effect of different irrigation regime (different levels of depletion of soil moisture) on yield and efficiency of sesame adi variety use of water. The treatments were established based on the levels of depletion of soil moisture for sesame $(\mathrm{MAD}=0.60)$. Five levels of depletion of soil moisture were then selected to evaluate the optimum irrigation schedule, namely SMD1 (60\%), SMD2 (80\%), SMD3 (100\%), SMD4 (120\%) and SMD5 (140\% of the recommended value, 0.60). The result showed that SMD4 has increased the yield and water use efficiency of sesame on a sandy loam textured soil significantly $(\mathrm{P}<0.05)$. Furthermore, the total requirement for crop water was $585.50 \mathrm{~mm}$. However, the lower level of depletion of soil moisture below the recommended value (SMD1 and SMD2) resulted in lower efficiency of both yield and use of crop water.
\end{abstract}

Keywords:Dubti, Irrigation scheduling, Sesame, Water use Efficiency.

DOI: $10.7176 /$ IEL/9-3-03

Publication date: April $30^{\text {th }} 2019$

\section{INTRODUCTION}

Irrigation means applying adequate water at the right time to crops in the right amount. [2]. to develop best management practices for irrigated areas, irrigation scheduling is important. [1]. There is considerable scope for improving the efficiency of these crops in water use through adequate irrigation schedules governing crop evapotranspiration. [12]. empirically deriving crop coefficient values for each crop based on lysimeter data and local climatic conditions. [7].

The irrigated area should be increased by more than $20 \%$ and the yield of irrigated crops should be increased by $40 \%$ in 2025 to secure food for 8 billion people. [4]. Therefore, with higher efficiency or productivity, water resources should be used. In order to achieve this objective, it is highly imperative to improve the productivity of agricultural water. Many researches have been conducted to gain experience in crop irrigation to maximize performance, efficiency and profitability, and water-saving irrigation investigations are still ongoing. [10]. the sustainable use of water in agriculture has become a major concern. The adoption of strategies for saving irrigation water and maintaining acceptable yields may contribute to the preservation of this ever more restricted resource. [11].

In most cases, irrigation fields in Ethiopia were not monitored before and after irrigation are due to their moisture content. Although irrigation has been practiced for a long time, the experience of farmers is very limited in this regard. Therefore, water management for irrigation is not efficient where modern irrigation systems in the middle Awash Valley developed four decades earlier. This is the worst case for farmers with the country's small farm owner. Thus, the practice of irrigation is one of the measures to increase crop production in Ethiopia, whose major economic development depends on agricultural production. Over the past four decades, the country has experienced severe drought, although there is ample water resource from precipitation, surface and sub-surface in its periphery.

There is no efficient and well-managed irrigation water practice in Afar, although irrigation has been practiced at different farm levels for a long time. There is very little or no information for the agro-pastoralist in the region about proper management of irrigation water and crop management practices.

Sesame (Sesamum indicum L.) is an important annual oil seed crop grown especially in developing countries as a rich source of oil, protein, calcium and phosphorus. Among oilseed crops, sesame is the most ancient oilseed known and grown by humans according to archaeological records. [5]. There are no definite findings on the origin of sesame, though Ethiopia is considered to be the center of cultivated sesame. [14]. 
Traditional irrigation practices are used in the study area to grow vegetables in various areas. However, there is no known requirement for both crop and irrigation water, including irrigation scheduling. Furthermore, the level of depletion of soil moisture for sesame should be 0.60. [7]. However, it is necessary to verify the recommendations on the operating environment as the requirement for crop water depends on the crop type (variety) and climatic condition. It is important to determine the actual need for crop water and the right time for water application (irrigation schedule) for effective use of the available water resource. This study was therefore carried out to determine the optimum irrigation schedule based on the level of depletion of soil moisture in Dubti for sesame (Adi). The information identified is important for increased crop production \& productivity, improved water management for irrigation, and environmental conservation. Therefore, this study aims to find out that irrigated agriculture has optimal irrigation water problems.

\section{MATERIALS AND METHODS}

\section{A. General Description of Study Area}

The experiment was conducted at the Dubti Pastoral and Agro-pastoral Research Center Research Site Farm, located in the northern part of the Ethiopian Rift Valley system at the lower part of the Awash Basin, Geographically, it is located between 11 o 39'0 versus 11 o 48'0 versus 041 o 6 versus 041 o 120 versus 041 o 120 versus 041 o Longitudes ranging from 339 to 381 (m.a.s.l.) and 0.03 to 0.3 percent. Erratic rainfall pattern with average annual precipitation of $222 \mathrm{~mm}$ characterizes the area. The minimum and maximum annual mean temperatures are 22.6 and 48.8 0C, respectively with an average of 35.7 0C and $2854.1 \mathrm{~mm}$ (Dubti meteorological station) mean annual evapotranspiration (ET). The source of irrigation water is Tandaho sugar factory primary canal which is suitable for irrigation purpose.

\section{B. Experimental Design}

For three consecutive years (2016 -2018), the experiment was conducted. It was arranged with three replications in randomizing complete block design. The treatment was rated for five levels of depletion of soil moisture (SMD). The recommended allowable depletion of soil moisture for sesame is $60 \%$ of the total available soil moisture used as 100\% SMD, as in ( R. G. Allen et al.,1998). The rates were $60 \%, 80 \%, 100 \%, 120 \%$, and $140 \%$, respectively, of SMD. The total number of plots was 15 , with each plot having a size of $4 \mathrm{~m} 2$. Sesame (Adi) variety was seeded at the area seed rate $(6.5 \mathrm{~kg} / \mathrm{ha})$ and all the recommended practices for the area were applied during the growing season.

\section{Climatic and Soil Data Collection}

Climatic data and Reference evapotranspiration Long-term (20years) monthly climate data of the Dubti area was collected at the Dubti meteorological station from the Afar Region Meteorological Service. Rainfall, maximum and minimum temperature, relative humidity and wind speed and hours of sunshine are the parameters included. Dubti area's monthly reference evapotranspiration was estimated using long-term climate data using the FAO CROPWAT 8 program.

Table 1. Monthly Reference Evapotranspiration of Dubti.

\begin{tabular}{|l|c|l|c|c|c|c|c|}
\hline Month & Jan & Feb & Mar & April & May & June & \\
\hline ETo(mm/day) & 6.40 & 5.70 & 6.95 & 7.37 & 7.30 & 6.89 & Average \\
\hline Month & July & Aug & Sep & Oct & Nov & Dec & \\
\hline ETo(mm/day) & 8.00 & 7.59 & 7.63 & 6.59 & 5.49 & 5.02 & \\
\hline
\end{tabular}

Table 2. Soil physical characteristics of study area

\begin{tabular}{lrrrrr}
\hline Soil Depth & FC \% & PWP \% & BD & \multicolumn{1}{c}{ TAW mm } \\
\hline $\mathbf{0 - 2 0}$ & 14 & 6 & 1.33 & 16.00 \\
$\mathbf{2 0 - 4 5}$ & 16 & 7 & 1.33 & 22.50 \\
$\mathbf{4 5 - 7 5}$ & 26.67 & 9 & 1.33 & 35.34 \\
$\mathbf{7 5 - 1 0 0}$ & 22.33 & 9 & 1.33 & 33.33 \\
Average & 19.75 & 7.75 & 1.33 & 26.79 \\
\hline
\end{tabular}

D. Crop Water Requirement

For research purposes, the requirement for crop water is determined by summing the net water depth required (dnet) throughout the crop growing season at each irrigation event. At each growth stage, the amount of water applied to the crop root zone was applied based on the level of depletion of soil moisture. The water balance formula was used to calculate the net irrigation requirement. [13].

$\mathrm{NIR}=\mathrm{d}_{\mathrm{net}}-\mathrm{P}_{\mathrm{e}}-\mathrm{GW}-\mathrm{SW}$ 
Where

$\mathrm{NIR}=$ Net irrigation requirement, $\mathrm{mm}$

$\mathrm{d}_{\text {net }}=$ Net depth of water required, $\mathrm{mm}$

$\mathrm{P}_{\mathrm{e}}=$ effective precipitation, $\mathrm{mm}$

$\mathrm{GW}=$ Ground water recharge, $\mathrm{mm}$

$\mathrm{SW}=$ Change in soil water content, $\mathrm{mm}$

The water table of the experiment site is deep enough and vertical towards the crop root zone was assumed as negligible. Hence, the groundwater recharge is negligible. The net depth of water required $\left(\mathrm{d}_{\text {net }}\right)$ was determined by the equation provided by. [6]

dnet $=\mathrm{TAW} \times \mathrm{Zr} \times \mathrm{P}$

Where

dnet $=$ Net depth of water required $(\mathrm{mm})$

$\mathrm{P}=$ Allowable soil moisture depletion of crop $(0.60)$

TAW $=$ Total available soil moisture $(\mathrm{mm} / \mathrm{m})$.

$\mathrm{TAW}=10 \times\left(\theta_{\mathrm{FC}}-\theta_{\mathrm{PWP}}\right) \times \mathrm{Zr}$

Where

TAW $=$ Total available soil moisture, $\mathrm{mm} / \mathrm{m}$

$\theta_{\mathrm{FC}}=$ Volume moisture content at field capacity, $\%$

$\theta_{\text {PWP }}=$ Volume moisture content at wilting point, $\%$

$\mathrm{Zr}=$ Effective crop root depth, $\mathrm{m}$

Effective Rainfall was computed using the reference [13].

Method and it is described in the following equations.

$\mathrm{Pe}=[\mathrm{P} \times(125-0.2 \times 3 \times \mathrm{P})] / 125$; for $\mathrm{P}<250 / 3$ (4)

$\mathrm{Pe}=125 / 3+0.1 \mathrm{P} ;$ for $\mathrm{P}>250 / 3(5)$

Where

$\mathrm{Pe}=$ Effective precipitation determined in $\mathrm{mm} /$ decade.

$\mathrm{P}=$ Total precipitation occurred in the crop growing season in the area, in $\mathrm{mm} /$ decade.

Gross irrigation requirement (GIR)

GIR is determined using the following formula Developed by [8].

$\mathrm{GIR}=\frac{\mathrm{NIR}}{(1-\mathrm{LR}) * \mathrm{E}_{\mathrm{a}}} * 100$

Where

$\mathrm{GIR}=$ Gross irrigation requirement $(\mathrm{mm})$

$\mathrm{NIR}=$ Net irrigation requirement $(\mathrm{mm})$

$\mathrm{LR}=$ Leaching requirement (fraction)

$\mathrm{Ea}=$ Application efficiency $(\%)$

E. Irrigation Scheduling

Irrigation frequency

The number of days between two subsequent irrigations, irrigation frequency, was determined by using the equation provided in reference [9].

$\mathrm{IF}=\frac{d_{n e t}}{\mathrm{RT} r}$

Where

IF = Irrigation frequency (days)

$\mathrm{d}_{\text {net }}=$ Net depth of water required (mm)

$\mathrm{ETc}=$ Crop evapotranspiration $(\mathrm{mm} /$ day $)$

The crop evapotranspiration used in irrigation frequency determination was estimated by multiplying crop coefficient with reference crop evapotranspiration, as in [3].

\section{F. Yield and Water Use Efficiency}

The yield and water use efficiency was selected as dependent variable. CWUE is the quantity of crop yield $(\mathrm{Kg} / \mathrm{ha})$ produced per unit depth $(\mathrm{mm})$ of water used, as in [12].

$$
\mathrm{CWUE}=\frac{\mathrm{Y}}{\mathrm{RT} c}
$$


Where

CWUE = Crop water use efficiency, $\mathrm{kg} / \mathrm{ha}-\mathrm{mm}$

$\mathrm{Y}=$ Yield of crop, $\mathrm{kg} / \mathrm{ha}$

$\mathrm{ETc}=$ Crop water requirement, $\mathrm{mm}$

\section{G. Data Collection and Analysis}

Sesame efficiency data on yield and water use have been recorded from three consecutive years. Using the general linear model (GLM) SAS 9.2 program, the results of yield and water use efficiency were subjected to variance analysis. The least significant difference (LSD) test was used to distinguish between the means of treatment at 5 percent probability.

\section{RESULT AND DISCUSSION}

\section{A. Crop Water Requirement}

On April 08, 2016-2018, the Sesame, Adi variety, was planted. As shown in Table 3, ten irrigation events with a total of $505.60 \mathrm{~mm}$ of irrigation water supplied throughout the growing period. During cultivation time, the amount of rainfall occurred was very small and the presence of irrigation water could demonstrate its significance.

Table 3.Crop water requirement and irrigation scheduling for (100\% MAD)

\begin{tabular}{ccrrr}
\hline $\begin{array}{c}\text { Irrigation } \\
\text { Event }\end{array}$ & $\begin{array}{c}\text { CWR } \\
\mathbf{m m}\end{array}$ & $\begin{array}{r}\text { Pe } \\
\mathbf{m m}\end{array}$ & $\begin{array}{c}\text { NIR } \\
\mathbf{m m}\end{array}$ & \multicolumn{1}{c}{$\begin{array}{c}\text { GIR } \\
\mathbf{m m}\end{array}$} \\
\hline $\mathbf{1}$ & 34.20 & 0 & 34.20 & 48.86 \\
$\mathbf{2}$ & 51.10 & 0 & 51.10 & 73.00 \\
$\mathbf{3}$ & 62.20 & 0 & 62.20 & 88.86 \\
$\mathbf{4}$ & 72.90 & 0 & 72.90 & 104.14 \\
$\mathbf{5}$ & 69.70 & 0 & 69.70 & 99.57 \\
$\mathbf{6}$ & 69.60 & 0 & 69.60 & 99.43 \\
$\mathbf{7}$ & 69.50 & 0 & 69.50 & 99.29 \\
$\mathbf{8}$ & 76.40 & 0 & 76.40 & 109.14 \\
Total & 505.60 & 0 & 505.60 & 722.29 \\
\hline
\end{tabular}

Note: $\mathrm{CWR}=\mathrm{Crop}$ water requirement; $\mathrm{P}$ e $=$ Effective rainfall; NIR $=$ Net irrigation requirement; GIR = Gross irrigation requirement

\section{B. Sesame Grain Yield}

The results of the three consecutive years of pooled mean showed that the use of different levels of depletion of soil moisture in Sesame production was significantly effective $(\mathrm{P}<0.05)$. The mean yield was gained as $732 \mathrm{~kg} /$ ha as described in Table 4. The maximum yield was obtained at 120 percent (SMD4) of the recommended level of soil moisture depletion (60 percent). The yield, however, decreased by 29.03 percent when the level of depletion of soil moisture was reduced by 40 percent from the recommended level. The least yield was obtained from SMD1, which was practiced with frequent irrigation or increased number of irrigation events with the most labor payments.

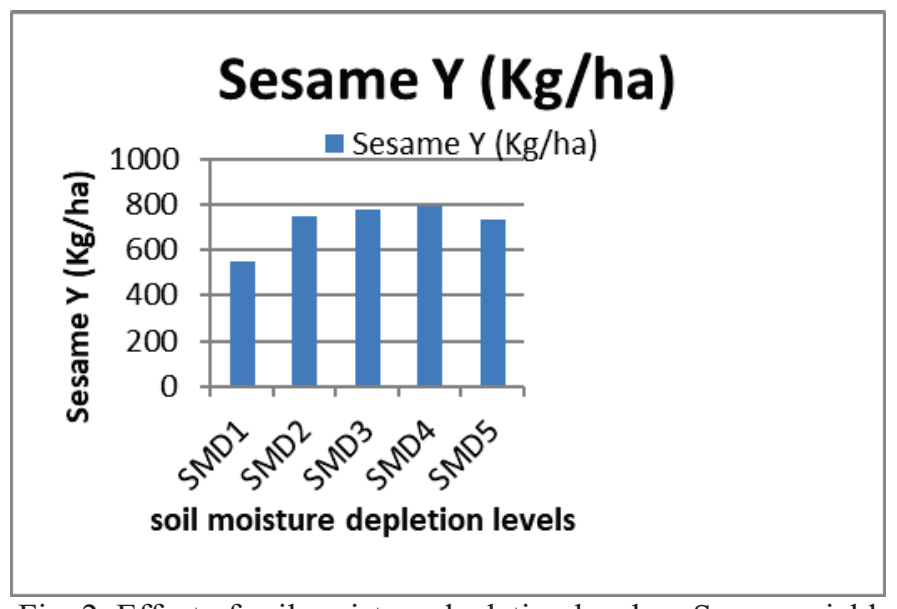

Fig. 2. Effect of soil moisture depletion level on Sesame yield 
Table 4. Response of Sesame (Adi) for different irrigation regimes

\begin{tabular}{|c|c|c|}
\hline \multirow[t]{2}{*}{ Treatment } & GY & CWUE \\
\hline & $\mathrm{Kg} / \mathrm{ha}$ & $\mathrm{Kg} / \mathrm{ha}-\mathrm{mm}$ \\
\hline SMD1 (60\%) & 550 & 1.81 \\
\hline SMD2 (80\%) & 750 & 1.85 \\
\hline SMD3 (100\%) & 775 & 1.53 \\
\hline SMD4 (120\%) & 788.5 & 1.30 \\
\hline SMD5 (140\%) & 735 & 1.04 \\
\hline Mean & 719.7 & 1.51 \\
\hline CV (\%) & 22.92 & 13.50 \\
\hline
\end{tabular}

Note: GY = Grain yield of Sesame; CWUE = Crop water use efficiency.

\section{Sesame Water Use Efficiency}

The result of various management levels of allowable depletion on the efficiency of Sesame water use was significant $(\mathrm{P}<0-05)$. The efficiency of an individual crop to convert irrigation water to Sesame products, as described in Table 4, was high in SMD4 treatment, which provided 23.36kg / ha - mm. The WUE minimum crop was $21.01 \mathrm{~kg} /$ ha-mm, showing the least efficacy of using water to make sesame grain. Efficiency in crop water use had increased tendency when the depletion of soil moisture rose from SMD1 to SMD4, but SM D5 was seen with the longest irrigation interval and crop stress leading to reduced efficiency in water use.

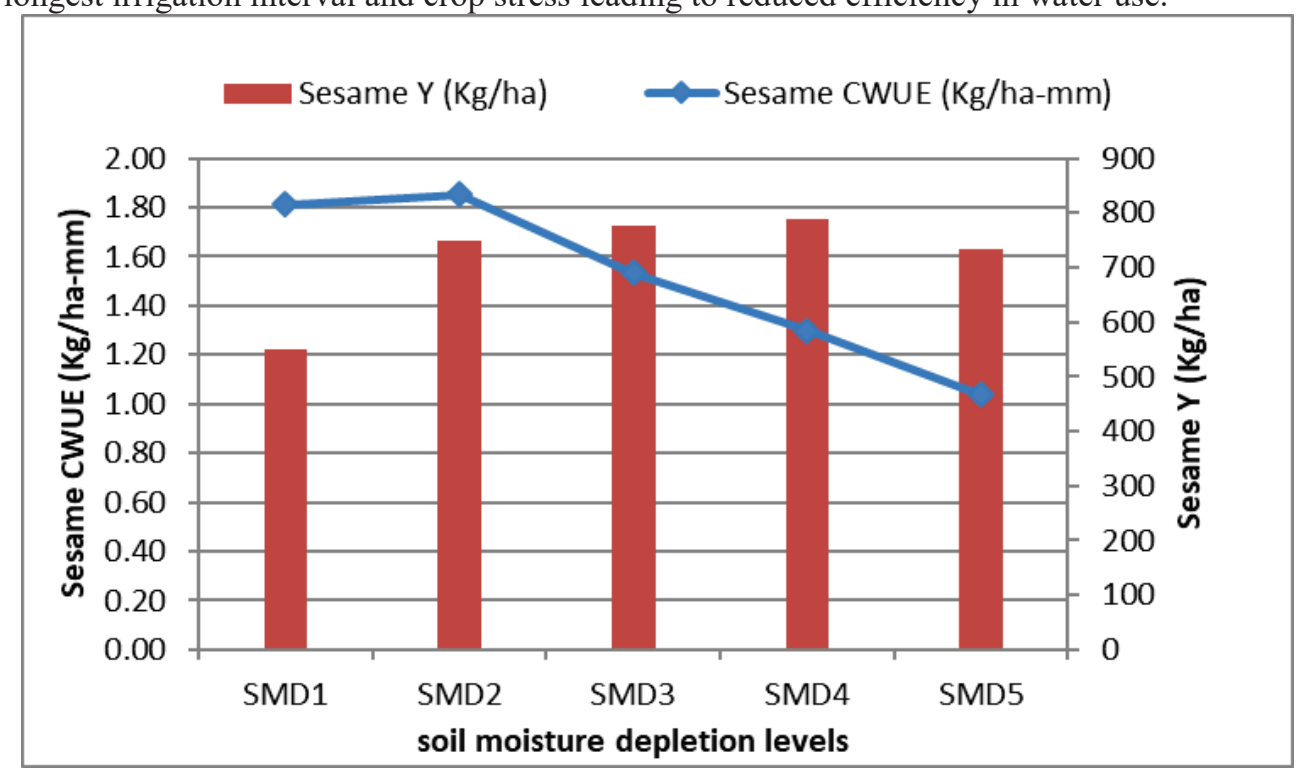

Fig. 3. Effect of soil moisture depletion level on Sesame Yield

\section{CONCLUSION AND RECOMMENDATION}

This study showed that managing the content of soil moisture at different levels of depletion influenced Sesame's efficiency in production and water use. Under the texture of sandy clay loam soil, the use of frequent irrigation is not recommended due to problem with water logging. Thus, by increasing the level of depletion of soil moisture by 20 percent over 55 percent depletion (or by depleting 66 percent of the total available soil moisture), the efficiency of yield and crop water use could be enhanced. This study additionally unconcealed that the suitable irrigation interval ought to be known for users within the space at every four crop growth stage to facilitate work.

\section{REFERENCES}

[1] Ali M. H., Paul H. and M. R. Haque, Estimation of evapotranspiration using a simulation model. J. Bangladesh Agril. Univ. 9(2): 257-266. 2011

[2] FAO Coping with water scarcity - an action framework for agriculture and food security. Rome, Italy. 2012.

[3] J. Doorenbos, and W.Pruitt, Crop Water Requirements (Revised Edition), Irrigation and Drainage Paper 24, FAO.Rome, 1977.

[4] Lascano, R.J., and R.E. Sojka, Preface. In: Irrigation of agricultural crops (Lascano, R.J., and Sojka, R.E. eds.), $2^{\text {nd }}$ edition, Agronomy Monograph no. 30. ASA-CSSA-SSSA publishing, Agricultural Water Management p. 664. 2007.

[5] Nayar, N.M. Sesame. In: Evaluation of crop plants (Ed.: N.W. Simmonds), Longman, London, pp. 231-233. 
1984.

[6] P.Savva, and K.Frenken, Crop Water Requirement and Irrigation Scheduling. Irrigation Manual, Module 4, FAO, Harare, 2002

[7] R. G. Allen, L. S.Pereira, D.Raes, and M.SMITH, Crop Evapotranspiration: Guidelines for Computing Crop Water Requirements, Irrigation and Drainage Paper No. 56, Food and Agricultural Organization (FAO), Rome, 1998.

[8] S. B.Awulachew, D. J.Merrey, A. B.Kamara, B.Van Koppen, F.Penning de Vries, E.Boelee, G. Makombe, Experiences and opportunities for promoting small-scale/micro irrig ation and rainwater harvesting for food security in Ethiopia, Colombo, Sri Lanka: IWMI, v. 86p, (Working paper 98), 2005.

[9] S.B.Tennakoon, and S. P.Milroy, Crop water use and water used efficiency on irrigated cotton farms in Australia, Agricultural Water Management, Vol. 61, 2003, pp.179-194.

[10] Sleper, D.A., S.L. Fales, and M.E. Collins, Foreword. In: Irrigation of agricultural crops (R.J. Lascano and R.E. Sojka, eds.), 2nd edition, Agronomy MonograpH no. 30. ASA-CSSA-SSSA publishing, 664p. 2007.

[11] Topcu G, Ertas A, Kolak U, Öztürk M, Ulubelen A Antioxidant activity tests on novel triterpenoids from Salvia macrochlamys. Arkivoc 7: 195-208. 2007.

[12] Tyagi, N. K., D. K. Sharma, and S. K. Luthra. "Determination of evapotranspiration and crop coefficients of rice and sunflower with lysimeter." Agricultural water management 45.1 (2000): 41-54.

[13] USDA (United States Department of Agriculture), Natural Resources Conservation National Engineering Handbook, Irrigation Guide, Natural Resource Conservation Service,. Washington DC,1997, 754p.

[14] Weiss, E.A.. Sesame. In: Oilseed crops. Longman Inc., New York, pp. 282-340. 1983. 